\title{
耐力低下が生じる鉄筋コンクリート造壁フレーム構造の 耐震診断による耐震性能評価法に関する検討
}

\section{PERFORMANCE EVALUATION USING SEISMIC SCREENING STANDARDS OF REINFORCED CONCRETE WALL-FRAME STRUCTURE WITH STRENGTH DETERIORATION}

松 井 智 哉*, 壁谷澤 寿海**

Tomoya MATSUI and Toshimi KABEYASAWA

\begin{abstract}
In this study, as the structure that is composed of members that ductility is different, response analysis of wall-frame structure modeled on level of member was carried out, results of that was compared with seismic performance in "the Seismic Screening Standards", the effect that member with strength deterioration affects seismic performance and applicability of evaluation using basic seismic index $E_{0}$ was examined as basic study. As the results, although the effect of strength deterioration has looseness according to the earthquake wave, it is possible that seismic capacity of structure that have a lot of deformability and strength deterioration could be overestimated in the seismic screening standards. And that behavior can be attribute damage concentration at a specific story.
\end{abstract}

Keywords : reinforced concrete, Wall-frame structure, strength deterioration, seismic screening standard, basic seismic index 鉄筋コンクリート，壁フレーム構造，耐力低下，耐震診断，保有性能基本指標

1. はじめに

耐震診断において広く活用されている「既存鉄筋コンクリート造 建築物の耐震診断基淮 ・同解説」1)では耐力低下が生じる（勒性が 異なる部材で構成されている）建物の評価の際には，1 質点系の応答 解析を基に定式化された勒性型保有性能基本指標を用いる.この指 標は，建物の構造的な耐震判定するための指標 1 つであり，最終的 な判定は, 脆性部材の有無, 累積強度指標等を含めて総合的に判定 している。これらの評価手法は簡便性をもたすといったこともあり， 耐力低下する建物の忘答性状を含めた一般的な評価法に至っていな いのが現状である，そこで，基礎的な研究として，部材レベルでモ デル化した建物の地震応答解析を通じて, 耐力低下が生じる部材が 建物の耐震性能に与える影響および影響因子について検討するとと もに，耐震診断基準における勒性型保有性能基本指標の適用性につ いて考察を行なった.

\section{2. 対象建物}

解析対象建物の架構図を図 1 に示す，解析対象とする建物は，6階 建連層耐震壁付鉄筋コンクリート構造である。ここで耐力低下は, 耐震壁のみで生じるとし，柱において耐力低下は生じないものとす る. 階高は 1 階が $4 \mathrm{~m}, 2 \sim 6$ 階が $3.6 \mathrm{~m}$ となっている， $x$ 方向は $6 \mathrm{~m}$ 間 隔の 3 スパンとし， $y$ 方向は $6 \mathrm{~m}$ スパンで純フレーム構面と壁フレー ム構面が並列に任意に構成される建物としている，建物の降伏機構 は, 梁端と 1 階柱脚部に降伏ヒンジをもつ梁降伏型の全体降伏を形 成するものとする，部材断面は全層同一なものとし，各部材の基本
となる断面および配筋を表 1 に示す. 重量は単位床面積当り $11.8 \mathrm{kN} / \mathrm{m}^{2}$ とし，使用する材料については，コンクリートの設計基準 強度が $21 \mathrm{~N} / \mathrm{mm}^{2}$, 柱, 梁の主筋の降伏強度を $345 \mathrm{~N} / \mathrm{mm}^{2}$, せん断補 強笳の降伏強度を $295 \mathrm{~N} / \mathrm{mm}^{2}$ と仮定した。解析対象方向は $x$ 方向とし 建物全体の強度に対する壁の強度の比率が異なる建物を想定して純

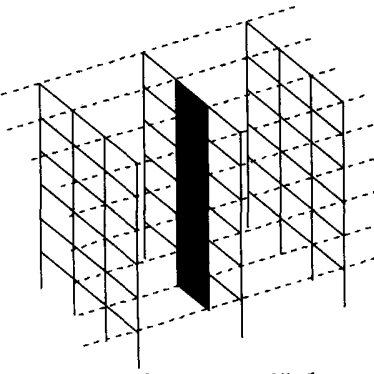

(a) 壁フレーム構造

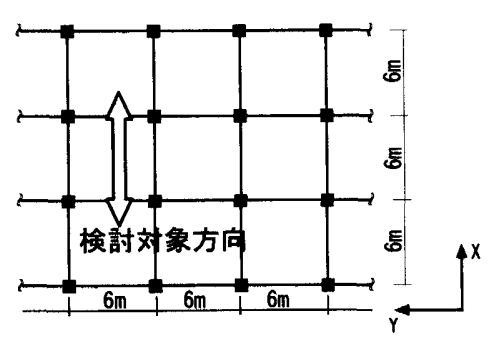

(b) 平面図

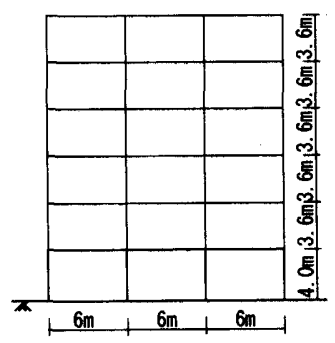

(c) 純フレーム構面の立面図

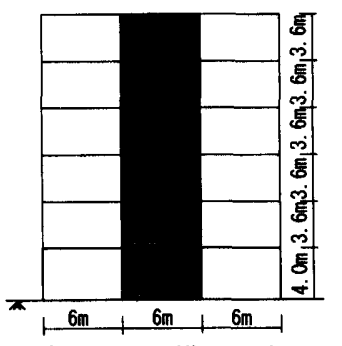

(d) 壁フレーム構面の立面図
図 1 対象建物の架權図
* 豊橋技術科学大学 博上: (工学)

** 東京大学地震研究所 教授.工博
Toyohashi University of Technology, Dr. Eng.

Prof., Earthquake Research Institute, The University of Tokyo, Dr. Eng. 
フレーム構面数と壁フレーム構面数の組合せを変えて解析モデルを 設定する.

\section{表 1 部材断面}

\begin{tabular}{|c|c|c|c|}
\hline \multirow{3}{*}{ 柱 } & \multicolumn{2}{|c|}{$\mathrm{B} \times \mathrm{D}(\mathrm{mm})$} & $800 \times 800$ \\
\hline & \multicolumn{2}{|l|}{ 主筋 } & $12-\mathrm{D} 25\left(p_{\mathrm{g}}=0.95 \%, p_{t}=0.32 \%\right)$ \\
\hline & \multicolumn{2}{|l|}{ 帯笪 } & 4-D13@100 \\
\hline \multirow{3}{*}{ 梁 } & \multicolumn{2}{|c|}{$\mathrm{B} \times \mathrm{D}(\mathrm{mm})$} & $450 \times 850$ \\
\hline & \multirow{2}{*}{ 主筋 } & 上端 & $5-\mathrm{D} 25 \quad\left(p_{i}=0.66 \%\right)$ \\
\hline & & 下端 & 3-D25 $\left(p_{t}=0.4 \%\right)$ \\
\hline \multirow{2}{*}{ 壁 } & \multicolumn{2}{|c|}{ 壁厚(mm) } & 200 \\
\hline & \multicolumn{2}{|c|}{ 綎横補強筋 } & 2-D13@200 ( $\left.p_{w}=0.635 \%\right)$ \\
\hline
\end{tabular}

\section{3. 構造物のモデル化}

本解析における構造物は, 純フレーム構面と壁フレーム構面の並 列結合によってモデル化することができる．また，ここではできる 限り実際の挙動を模擬することを念頭において部材レベルでモデル 化を行なう（図 2, 図 3).

耐震壁は, 耐力低下性状を考虑するため, アイソパラメトリック 耐震壁モデルを用いる. 本モデルの特徴は, 図 4 に示すようにパネ ル要素と柱, 梁部材で構成されており, パネル要素にアイソパラメ トリック要素を用いることにより，せん断力・モーメント・軸力の 相互作用を考虑でき，曲げ降伏後のせん断破壊といった複雑な挙動 を表現できることである，側柱は，軸方向の剛性のみを考虑し非線 形ばねモデルを用い，梁の曲げは剛，軸方向は弾性としている，パ ネル要素は, 2 軸応力下における材料の力学的特性を考虑するために アイソパラメトリック要素を用いて，コンクリートの構成則には回 転ひび割れモデルを採用し，コンクリートの䉓ひずみに対して直 交する引張ひずみによって圧縮強度を低減させる方法をとっている。 負勾配領域における剛性は, 初期剛性の 0.001 倍とした．鉄筋は軸方 向のみの剛性を考虑し，履歴モデルはバイリニアモデルとしている． 本モデルに関するモデル化の詳細な理論及び検証については文献 2),3),4)にまとめられている.

建物に配置された耐震壁の挙動を考えたとき，周辺部材の影響を 考虑する必要がある．ここでは直交梁を単独で耐震壁に取り付ける ことにより直交梁の効果を考慮することにする．モデル化方法は，

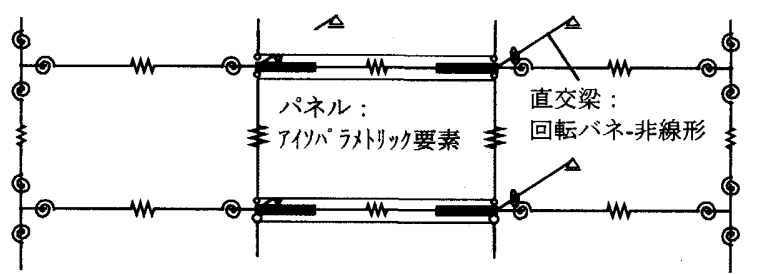

図 2 壁フレーム構面のモデル化

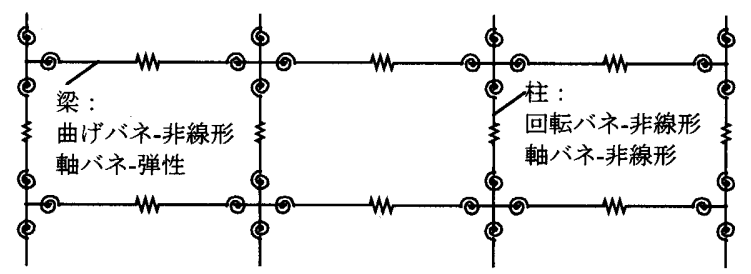

図 3 純フレーム構面のモデル化
次に示す梁のモデル化と同様である.

梁と柱には，剛域を考虑した弾塑性材端バネモデルを用いる．回 転バネの復元力特性は Tri-linear 型とし，履歴特性に Takeda モデルを 用いる. 復元力の各折れ点は曲げひび割れ，曲げ降伏に対応すると し復元力特性は文献 5)の算定方法に従った. 降伏時变形は, 診断基 準において標準的な曲げ柱は変形角 1/150 で降伏するとしていること から，復元力特性における降伏時の変形が $1 / 150$ (図 6 において $\left.D_{y}=1 / 150\right)$ となるように設定した. 降伏後の剛性は初期剛性の 0.001 倍とした．梁についてはスラブの協力幅は片側あたり $1 \mathrm{~m}$ としてスラ ブ筋を考慮し，曲げ剛性增加率 $\phi$ を 2 としている。柱の軸バネは非 線形として Axial-Stiffness モデル 6)を用い（図 7)，圧縮側は弾性，引 張側は鉄筋のみを考慮するとして剛性を低下させ，柱全主筋の引張

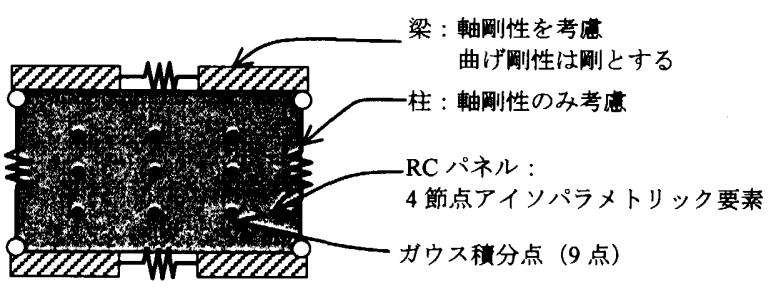

図 4 アイソパラメトリック耐震壁モデル

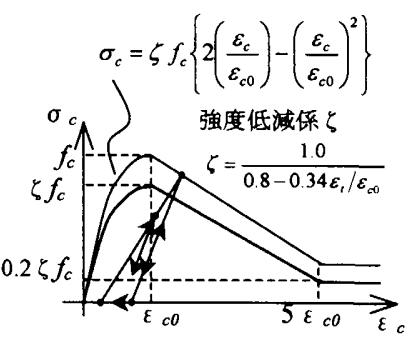

a) 压縮側

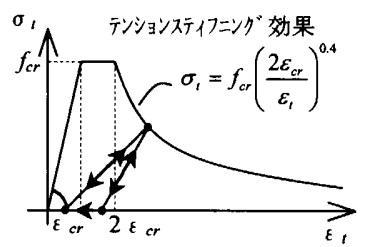

b) 引㲀侧
図 5 積分点におけるコンクリートの材料モデル

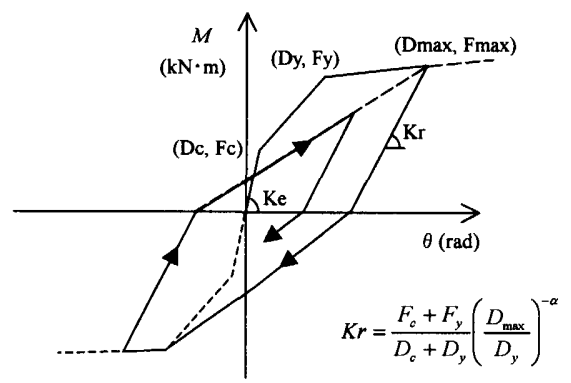

図 6 曲げバネの復元カ特性 (Takeda Model)

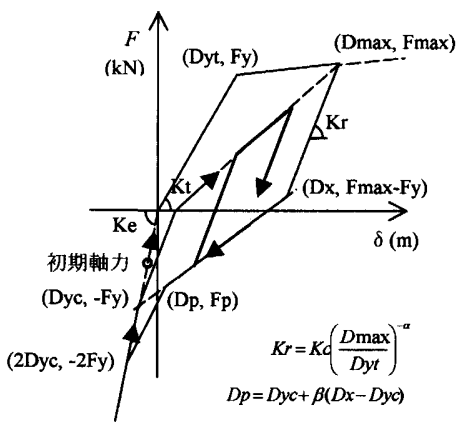

図 7 軸バネの復元力特性 (Axial-Stiffness Model) 
降伏耐力で引張降伏するとし，初期軸力を考虑する．降伏後の剛性 は初期剛性の 0.001 倍とした. 梁の軸バネは弾性とする. 質量は支配 面積あたりの質量を節点に集中質量として与える，基礎は固定とす る.

\section{4. 解析方法と入力地震動}

3 節で示したモデル化方法により，静的変位増分解析と地震応答解 析を行なった. 地震応答解析において数值積分法は Newmark-B 法 （ $\beta=0.25 ）$ を用い, 時間刻みを $0.002 \mathrm{sec}$ とした. 减衰は瞬間剛性比 例型で減衰定数は 1 次固有周期に対して 5\%とした。剛性変化による 不釣合力は, 次のステップで外力に足し合わせて解除する. 入力地 震動は TOH(1978 年宮城県沖地震, 東北大学の記録[NS 成分]), ELC (1940 年 Imperial Valley 地震, El Centro の記録[NS 成分]), JMA (1995 年兵庫県南部地震, 神戸海洋気象台の記録[NS 成分]), HAC （1968 年十勝沖地震，八戸港湾の記録[EW 成分]), TAK（1995 年兵 庫県南部地震, JR 鷹取駅の記録[NS 成分]）の 5 種類を用いた. 入力 地震動の加速度応答スペクトルを図 8 に, 各諸元を表 2 に示寸. 各 解析モデルに対して地震動の最大加速度レベルを変えて入力する. 入力波の継続時間は, 加速度が最大加速度のほぼ $20 \%$ 以下になるま でとした。

\section{5. 静的解析結果}

構造物の基本性状として, 外力分布を逆三角形分布と仮定した静 的解析による 1 層層間変形角 $1 / 75$ 時の部材の降伏状況を図 9 に示寸. 壁フレーム構造（純フレーム構面 : 壁フレーム構面=4:1）は, 純フ レーム構造と異なり，1 層柱脚と柱頭が降伏し, 層崩壊メカニズムを 形成しているのがわかる.

次に, 壁フレーム構面の数によって直交梁による押さえ効果が変 わってくると考えられることからその影響についてみてみる. 図 10 は，直交梁なし対する直交梁ありの場合の耐震壁の最大せん断力の 増加率を示したものである. 壁フレーム構面が増えるにつれてせん 断力の増加率は小さくなる傾向がみられる. 図 11 は, 耐震壁の復元 力特性の一例を示したものである. 直交梁の効果により, 耐力低下

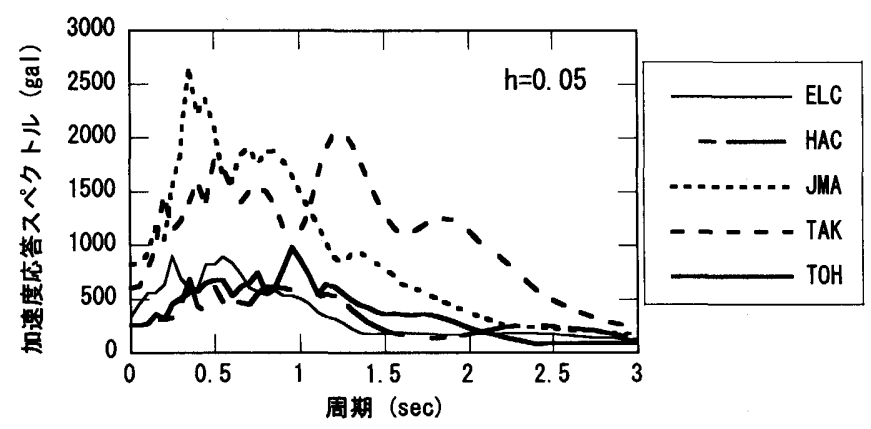

図 8 加速度応答スペクトル（原記録）

表 2 入力地震動

\begin{tabular}{|c|c|c|c|}
\hline 入力波名 & $\begin{array}{c}\text { 原波形最大加速度 } \\
\text { (gal) }\end{array}$ & $\begin{array}{c}\text { 原波形最大速度 } \\
\text { (kine) }\end{array}$ & $\begin{array}{c}\text { 継続時間 } \\
\text { (sec) }\end{array}$ \\
\hline ELC & 341 & 34.8 & $0 \sim 20$ \\
\hline HAC & 186 & 42.9 & $0 \sim 30$ \\
\hline JMA & 836 & 85.4 & $1 \sim 15$ \\
\hline TAK & 612 & 124.2 & $0 \sim 18$ \\
\hline TOH & 262 & 40.9 & $5.6 \sim 25$ \\
\hline
\end{tabular}

域の勾配がやや大きくなる（負方向に）といった影響が確認できる.

\section{6. 耐震診断基準における保有性能基本指標}

耐震診断基準で用いられる保有性能基本指標 $E_{0}$ は，建物が保有す る耐震性能を評価する基本指標であり，建物の終局強度から算定さ れる強度指標 $C$ と破壊形式および勒性性能より算定される勒性指標 $F$ を組み合わせて算定する，本論における単一部材で構成される純 フレーム構造の保有性能基本指標 ${ }_{c} E_{0}$ は，(1)式で表される，建物が異 なる勒性性能の部材をもつ場合には，勒性指標の小さい順に部材を 分類し（最大 3 グループ），強度型保有性能基本指標もしくは勒性型 保有性能基本指標のいずれかを用いて算定する。ここでは，検討対 象としている勒性型保有性能基本指標を用いて, 壁フレーム構造の 保有性能基本指標 ${ }_{w} E_{0}$ は，(2)式で表される.

純フレーム構造（単一部材で構成される建物）：

$$
{ }_{c} E_{0}=\frac{n+1}{n+i} C_{c} F_{c}
$$

壁フレーム構造（靭性性能の異なる部材で構成される建物）：

$$
{ }_{w c} E_{0}=\frac{n+1}{n+i} \sqrt{\left(C_{w} F_{w}\right)^{2}+\left(C_{c} F_{c}\right)^{2}}
$$

ここで, $C_{w}$ : 壁の強度指標, $C_{c}$ : 柱の強度指標， $F_{w}$ : 壁の勒性指 標, $F_{c}$ : 柱の勒性指標, $n$ : 建物回数, $i$ : 対象としている階の階数で ある. $(n+1) /(n+i)$ は，外力分布による補正係数であり，本検討では 1 層を対象とするため 1 となる.

靶性指標 $F$ は, 弾性応答せん断力係数 $C_{e}$ と降伏せん断力係数 $C_{y}$ の 比として表される.

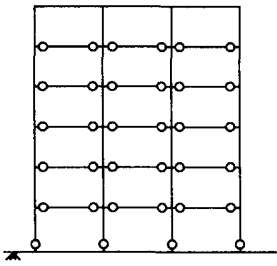

(a) 純フレーム構造

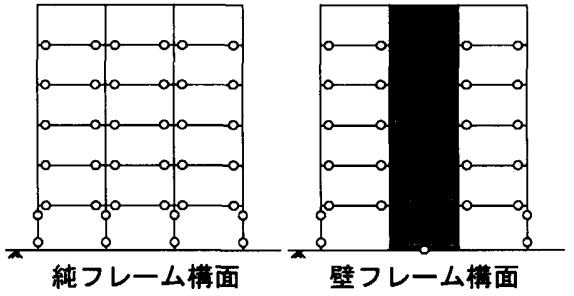

(b) 壁フレーム構造
図 9 部材の降伏状況

（1 層層間変形角 $1 / 75$ 時， O : 降伏)

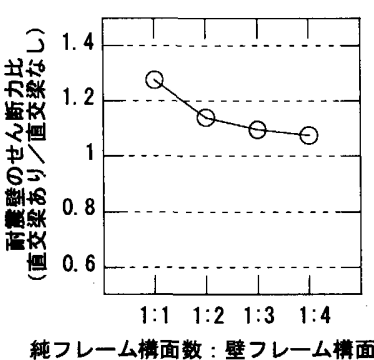

図 10 直交梁が耐震壁の 復元力特性に与える影響 (せん断力増加率)

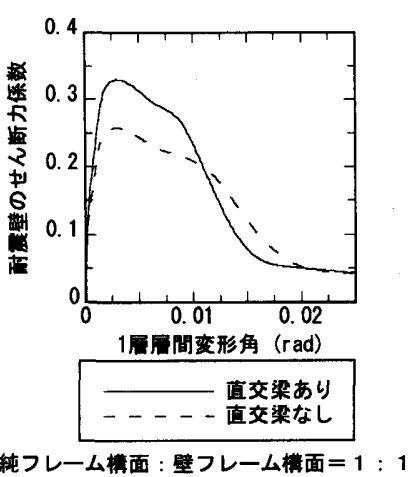

図 11 直交梁が耐震壁の 復元力特性に与える影篦 (復元力特性) 
$F=C_{e} / C_{y}$

耐震診断基準では，完全弾塑性系におけるエネルギー一定式を Dtri モデル振動系の応答解析に基づき修正し，最大塑性率 $\mu$ と $C_{e} / C_{y}$ の 関係から次式を曲げ柱の勒性指標の算定式としている ${ }^{13,7) . ~}$

$$
F=\frac{C_{e}}{C_{y}}=\frac{\sqrt{2 \mu-1}}{0.75 \times(1+0.05 \mu)}
$$

\section{7. 解析パラメータ}

解析パラメータは壁の強度とし，建物全体の強度指標に対する壁 の強度指標を強度比として次のように表す。

壁の強度比 $\quad \beta=\frac{C_{w}}{C_{w}+C_{c}} \quad(0 \leqq \beta \leqq 0.65)$

このとき, 柱の強度指標を一定（=0.28）とし，壁の強度指標は静 的弾塑性解析結果による壁の最大耐力とした $\left(0 \leqq C_{w} \leqq 0.52\right)$. 壁の 強度比が大きくなると壁が増加することになり，建物全体の強度も 增加することになる．本解析における純フレーム構面数と壁フレー 厶構面数の組合せと壁の強度比 $\beta$ の関倸を表 3 に示す.

図 12 は，柱の曲げバネに Takeda モデルを用いた純フレーム構面 の地震応答解析結果から, 最大応答塑性率と $C_{y} / C_{e}$ の関係を示したも のである.ここでは $C_{y}$ をパラメータとして解析を行ない，静的弾塑 性解析から得られた層間変形角 $1 / 150$ 時のせん断力係数とした. 入力 波 TOH において塑性率が大きくなっているものの，式（4）による 評価は応答解析結果を概ね包絡すると判断して，それにより(4)式か ら，柱の勒性指標 $F_{c}$ は，1.75，2.1，2.6，2.94 と設定し，解析におい て建物が倒壊する条件は，応答变位が表 4 の層間変形角に達する場 合とする，壁の勒性指標 $F_{w}$ は，静的弾塑性解析結果から耐震壁パネ ルの積分点の半分以上においてコンクリートが軟化域になった時 （壁のせん断破壊とする）の変形量を解析結果による耐震壁の終局 変形として定め, その変形に対応する値とした．このとき，壁の勒 性指標と変形角の対応関係は， $F_{w}=1$ で $1 / 250, F_{w}=1.27$ で $1 / 150$, $F_{w}=1.5$ で 1/125， $F_{w}=2$ で 1/80 と仮定して，これらを結ぶ折れ線で近 似し（図 13）， $F_{w}=1.4 ， 1.63 ， 1.82$ と設定した（解析モデル上では， 壁厚を $150,200,250 \mathrm{~mm}$ に対応)。

図 14 に静的解析の結果の一例（純フレーム構面 : 壁フレーム構面 $=2: 1 ） と し て$ 柱部材と壁部材および解析建物全体の負担せん断力

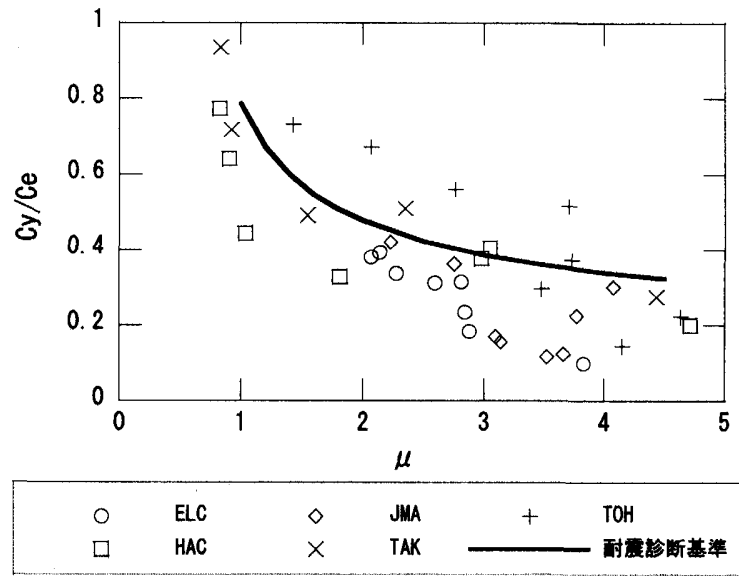

図 12 式(4)による応答推定値と地震応答解析結果
（ベースシヤー係数）を示す，柱部材は，塑性率 1 あたりで柱脚が 降伏し, 柱部材のベースシヤーは塑性率 2 程度で柱頭が降伏するま で漸増していく，解析結果による耐震壁の終局変形角（図中 $\triangle$ 印） は，他の解析ケースも含めて，耐震壁の耐力が最大耐力のおよそ 0.78〜0.85 倍に低下したときの変形となっている.

固有值解析から得られた解析モデルの基本周期は，0.26〜0.51 sec である. 固有周期の違いにより, 評価される耐震性能にばらつきが

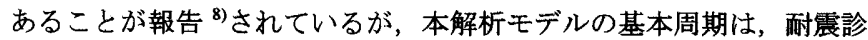
断基淮上ではほぼ適用籁囲内となっている.

表 3 純フレーム構面数と壁
フレーム構面数の組合せと
壁の強度比 $\beta$
\begin{tabular}{|c|c|c|}
\hline $\begin{array}{c}\text { 壁の } \\
\text { 強度比 }\end{array}$ & $\begin{array}{c}\text { 純フレーム } \\
\text { 構面 }\end{array}$ & $\begin{array}{c}\text { 壁フレーム } \\
\text { 構面 }\end{array}$ \\
\hline 0 & 1 & 0 \\
\hline 0.17 & 10 & 1 \\
\hline 0.31 & 4 & 1 \\
\hline 0.43 & 2 & 1 \\
\hline 0.53 & 1 & 1 \\
\hline 0.64 & 1 & 4 \\
\hline
\end{tabular}

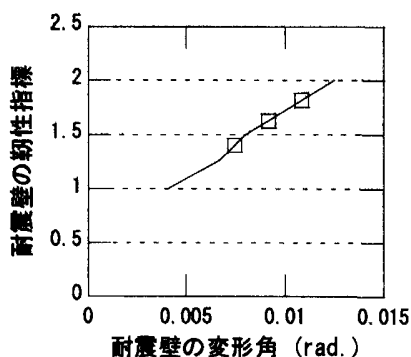

图 13 耐祳壁の終局变形と

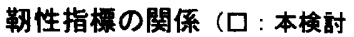
で設定した壁の䩗性指楫)

表 4 曲げ柱の䳬性指標 Fに対する局間変形角および塑性率

\begin{tabular}{|c|c|c|}
\hline 勒性指標 $F$ & 層間変形角 & 塑性率 \\
\hline 1.27 & $1 / 150$ & 1 \\
\hline 1.75 & $1 / 100$ & 1.5 \\
\hline 2.1 & $1 / 75$ & 2 \\
\hline 2.6 & $1 / 50$ & 3 \\
\hline 2.94 & $1 / 38$ & 4 \\
\hline
\end{tabular}

柱降伏变位を基篗とした塑性率 $\mu$

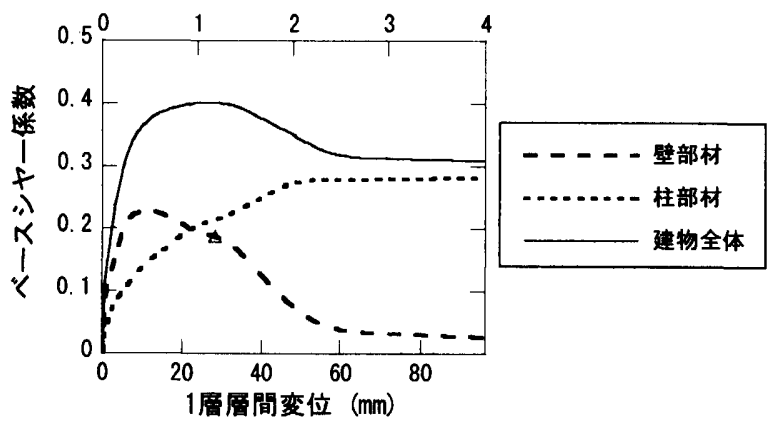

図 14 壁フレーム構造のスケルトンカーブ

\section{8. 解析結果}

図 15 に強度比 $\beta$ と応答解析から得られた塑性率の関係を示寸。こ こで塑性率は，柱の降伏変形つまり変形角 $1 / 150$ に対する 1 層層間変 形の各入力における最大変形として求めている. 図 15(a),(b)について みると， $\beta=0$ は純フレーム構造であり，強度比 $\beta$ が大きくなると壁 が付加されて建物全体の強度は大きくなっているにも関わらず，同 じ地震動レベルでも塑性率が大きくなるところが存在する.

図 15 中の○印は，解析において壁がせん断破壊したと判断される 最小入力レベルをプロットしたものである．壁がせん断破壊に達し ない領域（○印より下の領域）では，壁の強度比 $\beta$ が増加するにつ れて応答が減少していくのに対し，壁がせん断破壊に至る領域（○ 印より上の領域）では純フレーム構造より壁フレーム構造の応答が 大きくなる場合があるといえる，入力波 $\mathrm{HAC} ， \mathrm{TOH}$ についても同様 
の結果を示した．また，強度比 $\beta$ が大きいところでは，全体の強度 に対する耐力低下の割合が大きいため，壁がせん断破壊する地動レ ベルを超えると強度比 $\beta$ が小さい場合に比べて急激に変形は増大す る傾向にある，しかし，入力波 TAK（図 15(c)）では塑性率が 0〜4 の範囲全体においてグラフは右下がりで強度比 $\beta$ が大きくなるにつ れて変形が减少する傾向にある.

勒性指標 $F$ は，地震応答と変形性能の関係を考虑して，エネルギ 一一定則に基づいて定められている。 それにより，耐震診断基準に おける保有性能基本指標 $E_{0}$ は, 勒性指標 $F$ と強度指標 $C$ との組合せ

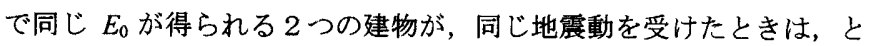
もにその建物の限界変形に対して同程度の応答変位が生じるという 考えから指標化されている. それに対し本論では, 地震動レベルを 最大加速度で表すとして，次のように図 15 の結果を耐震診断基淮に よる評価と対态させてみてみる，図 16 に，各モデルにおいて柱の靭 性指標に対応する塑性率に達するときの地震動レベル（最大加速 度） $k_{w c}$ を純フレーム構造（ $\beta=0 ）$ の場合の地震動レベル $k_{c}$ で基準化 した値と ${ }_{w c} E_{0} / E_{c} E_{0}$ を耐震性能比として示す.これは, 図 17 の網掛计 部分で表されることになる壁が付加されたことによる影響をどのよ うに評価しているかを比べることになる.

図 16(a-1), (b-1)，(c-1)のように $F_{c}$ が比較的小さい建物では, 耐震診 断の評価は解析結果のほぼ下限値をとる. 一方, $(\mathrm{a}-2,3,4),(\mathrm{b}-2,3,4)$, (c-2,3)のように $F_{c}$ が大きい建物では, 耐震診断における耐震性能比 は, 壁の強度比 $\beta$ が大きくなるにつれて増加しており壁が増えた分 耐震性能を大きく評価するのに対し, 解析結果による耐震性能比は, 壁が少ないところで 1 以下と小さくなる場合があり，異なる（診断 基淮においては過大評価となる）傾向を示し，その傾向は $F_{c}$ が大き くなっていくほど強い, また, 図 16(a-2), (b-2), (c-2)でみるように $F_{w}$ が大きくなるほど而震性能比は増加の傾向にある, つまり, 建物が 崩壊に至るまでの耐力低下の程度を表すことになる強度比, 柱の勒 性指標, 壁の勒性指標の相関関係により影響を受ける。

耐震壁性能比が 1 以下となる原因の 1 つに, 壁がせん断破壊する 層は，耐力が低下することにより，他層に比べて剛性の低下が著し く，せん断破壊後にその層に変形が集中する特有の現象が挙げられ る. 図 18 に同じ入力地震動に対して純フレーム構造と壁フレーム構 造の階ごとの水平変位を示す. 全体では壁フレーム構造の変形が小 さいが，1層では逆に変形が大きくなっており，損傷が大きく集中し た変形分布となっていることがわかる.

\section{7. まとめ}

異なる勒性部材で構成される建物として整形な壁フレーム構造を 想定して部材レベルの地震忘答解析を行い, 勒性限界以降に耐力低 下の生じる耐震壁の影響を考慮した応答性状について検討するとと

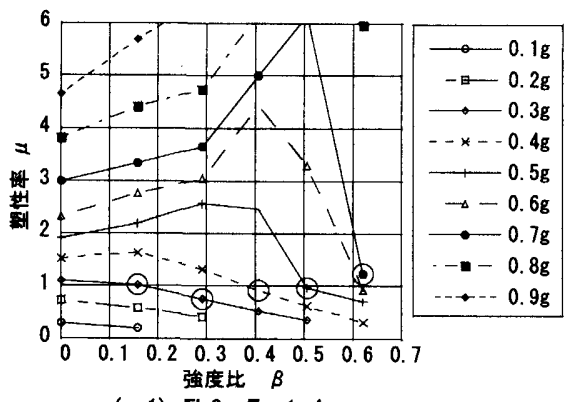

(a-1) ELC, FW=1. 4

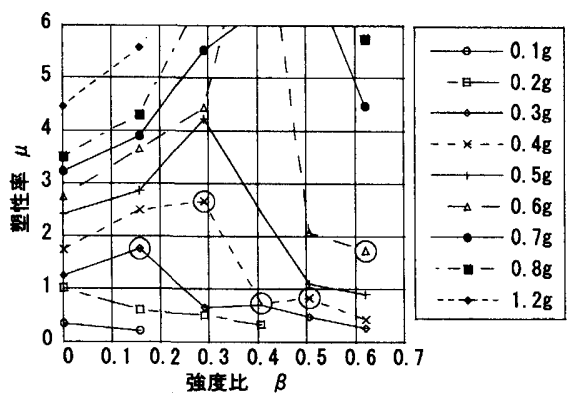

(b-1) JMA, FW=1. 4

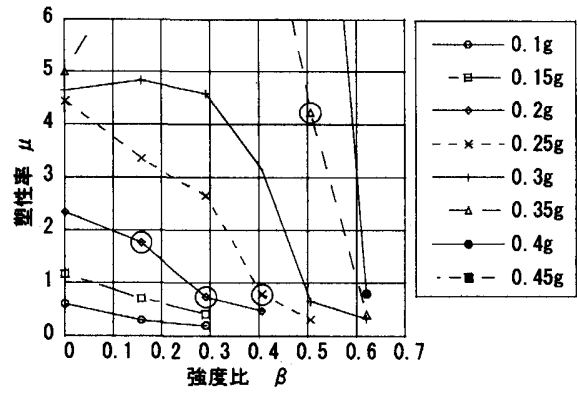

(c-1) TAK, FW=1. 4

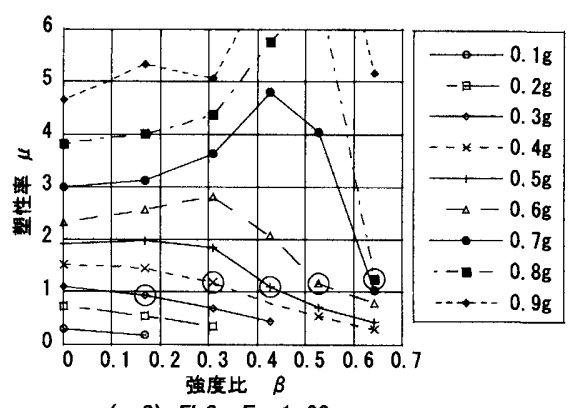

(a-2) $E L C, \quad F W=1.63$

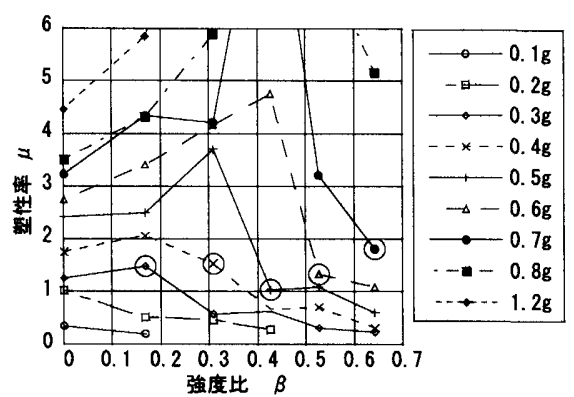

(b-2) JMA, FW=1. 63

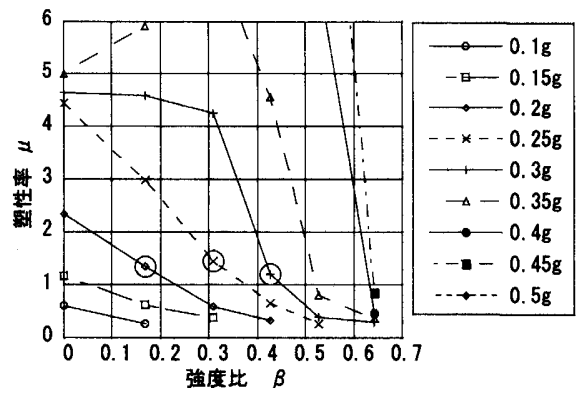

(c-2) TAK, FW=1. 63

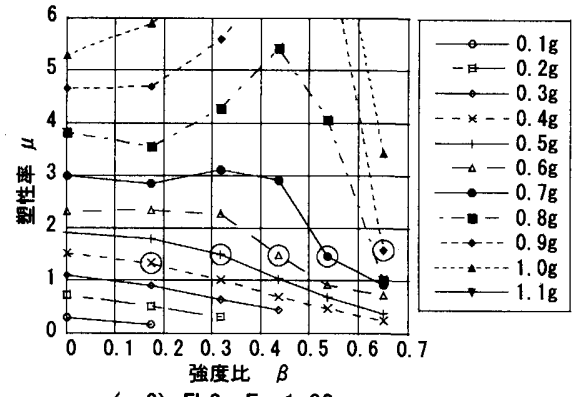

(a-3) ELC, FW=1. 82

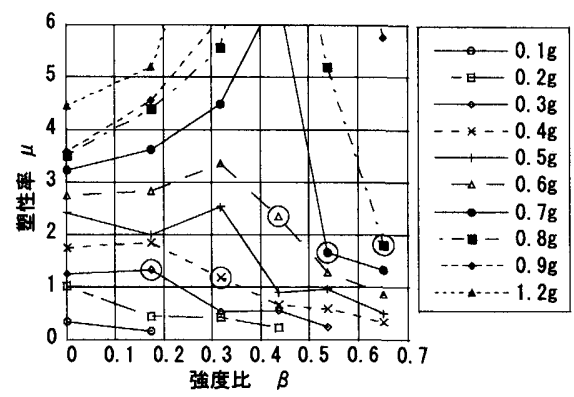

(b-3) JMA, Fw=1. 82

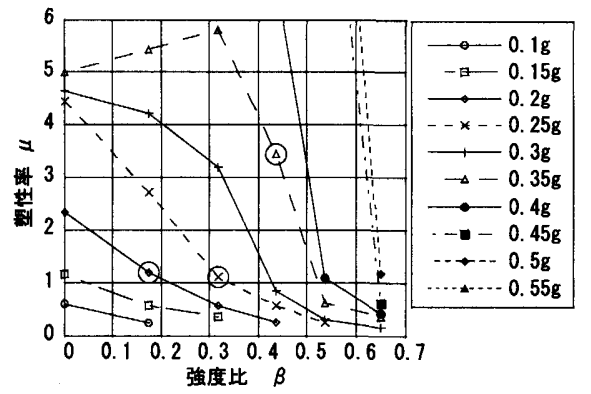

(c-3) TAK, FW=1. 82

図 15 壁の強度比と塑性率の関係（O：耐震壁が終局変形に達した入カレベル） 
もに, それらの解析結果を耐震診断基淮における保有性能基本指標 と比較することにより，勒性型保有性能基本指標の適用性について 検討した. なお, 本論で用いた耐震性能比は, 地震動の最大加速度 を耐震性能の尺度として表したものであり，相対的な比較を試みた として，以下に本解析において得られた知見について示す。

本検討で用いた耐震性能比は, 地震波によって大きなばらつきを もつものである. 比較的柱の勒性指標 $F_{c}$ が小さい建物では, 勒性型 保有性能基本指標による評価は, 耐震性能を過小評価する傾向にあ るが，診断基準において多少安全側の評価をすることを許容すれば 評価值として問題ない. 比較的柱の勒性指標 $F_{c}$ が大きくかつ壁の強 度比がそれほど大きくない建物では，勒性型保有性能基本指標によ る耐震性能は, 大局的にみて解析結果と比べて過大評価の傾向にな る場合がある，過大評価となる原因の 1 つとして，多層建物におい て耐力低下が生じる層に損稘が集中する特有の現象が挙げられる.

\section{参考文献}

1）日本建築防災協会：2001 年改訂版 既存鉄笳コンクリート造建物の耐震 診断基海同解説， 2001

2）陳少華, 壁谷澤寿海 : 非線形解析における鉄筋コンクリート耐震壁のモ デル，コンクリート工学年次論文集，Vol.21， No.3，pp.763-768，1999.6

3）松井智哉，壁谷澤寿海：正負繰返し载荷を受ける鉄筋コンクリート造耐 震壁の非線形解析, 日本建築学会大会学術講演梗概集, C-2, pp.291-292, 2004

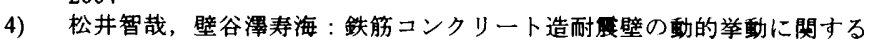
解析的研究, 日本地震工学会-2004 梗概集, pp.430-431，2005

5）日本建築学会：鉄筋コンクリート造建物の勒性保証型耐震設計指針・同 解説, 1999

6）壁谷䨕寿海，小谷俊介，青山博之：耐震壁を有する鉄筋コンクリート楼 造物の非線形地震态答解析, 第 5 回コンクリート工学年次諈演会諈演論 文集, pp.213-220, 1983
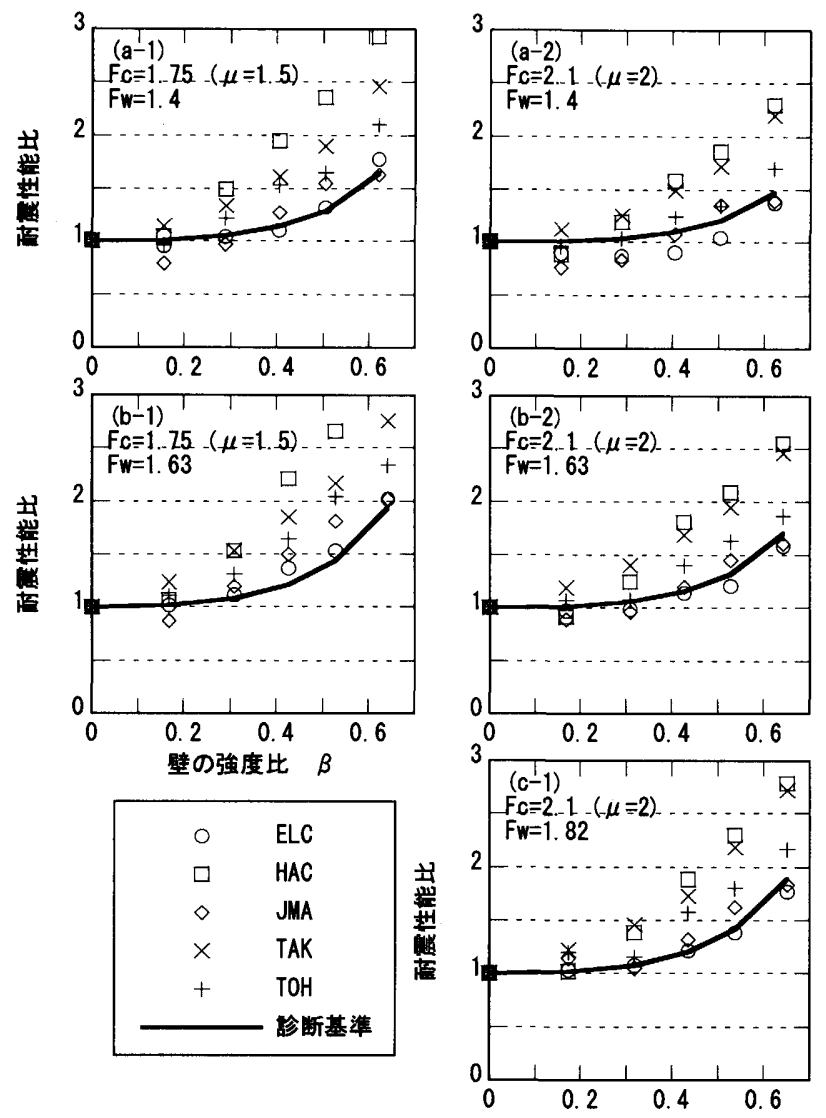

図 16 耐震性能比と壁の強度比の関係
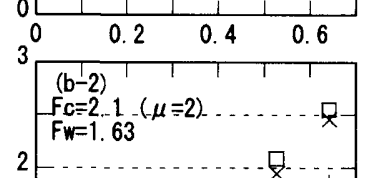

7）梅村鬼：鉄筋コンクリート建物の動的耐震設計法・続（中層編）， 1982.

8）青野松雄・久保哲夫・阿知波敏宏 : 動的地震応答解析を用いた耐震診断 による構造耐震指標值の検証（その 2 : 建物の周期をパラメータとした 結果)，日本建築学会大会学術講演梗概集， C-2, pp.959-960, 2003.9

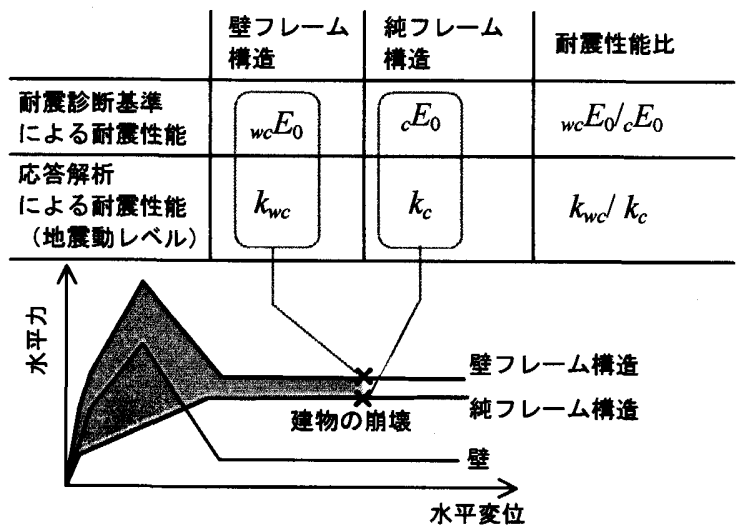

図 17 耐震牾断基準及び応答解析による耐震性能
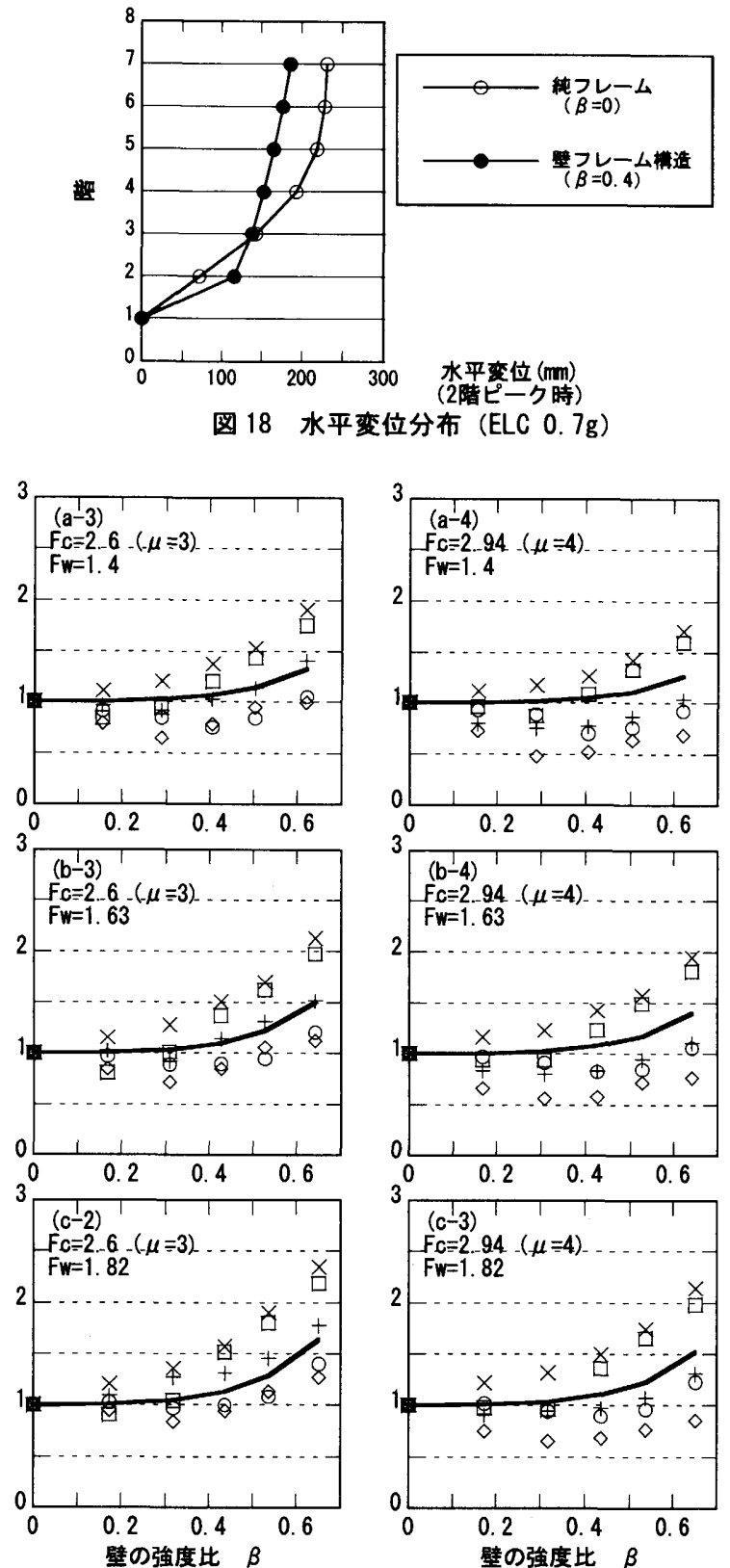